\title{
Application and Justification of Eclectic Approach (an Innovative Teaching Style) for ELT Practitioners in both Private and Public Universities in Bangladesh
}

\author{
Sumya Alam (iD \\ Lecturer, Department of English, BSMRSTU, Gopalganj-8100, Dhaka, Bangladesh \\ $\triangle$ Corresponding Author: Sumya Alam, E-mail: summasumya@yahoo.com
}

\section{ARTICLE INFORMATION ABSTRACT}

Received: December 08, 2020

Accepted: January 03, 2021

Volume: 3

Issue: 1

DOI: $10.32996 /$ ijels.2021.3.1.3

\section{KEYWORDS}

Eclectic Approach, Needs Analysis, Lesson Plan, Class Objective, Innovative Technique, Text, Implications, Problems, Solution, Implied Suggestion

The use of modern innovative techniques is an essential requirement for language pedagogy. One single method cannot meet all the needs of learners in language teaching. The purpose of this paper is to figure out the contextual application of eclecticism and compare two perspectives of learning which relates to public and private educational institutions. (Reference: both AIUB and BSMRSTU where I had been teaching for years). This study intends to draw the picture of real-life teaching experiences in both private and public universities. My focus will be on justification of practicing all four skills, specially listening and speaking skill through eclecticism. It is all about a teacher's unique innovations and his/her own creations to cover up all skills in one lesson. To conduct this research, a comparative study based of literature review was done to find out real problems of each institution. Some new innovative techniques and activities have been applied in learning and acquiring English in my classroom. All the students were given some tasks and they were asked to follow some instructions given. They became interested to accomplish all the tasks and learn lessons promptly. My goal is to talk about how successful a teacher can be to introduce a new technique. For example, teachers are suggested here to practice on the basis of 'realia' like playing and listening songs and music videos as innovative texts to exercise on all for skills. At last, the general purpose of this paper is to discuss a very authentic new technique, its future implications, results, problems and solutions. To talk about these, limitations of all other single methods and some current practices will be mentioned to investigate learners' needs on the basis of "Needs Analysis". Some solutions will be suggested at the very end of this paper.

\section{Introduction}

To keep pace with today's global world, the teaching of English cannot be taken aside since it is the most common lingua franca everywhere around the world. English learning has its importance to fulfill some basic purposes like in academic, commercial business and communicative sectors; English is used as an international language and the development of technology. It has been playing a vital role in many other sectors including technology, medicine, engineering, tourism etc. and so on for a long day. In education, for getting a higher degree and studying abroad or making a research paper or reading many books, magazines, and newspapers written in English, it is very much needed to have minimum knowledge of English. The students of tertiary level already got exposed to leaning English as a second language from their schools and college settings. To teach students, teachers have been following many methods since many years, for example, The Grammar-Translation Method (GTM), The Direct Method, the Structural- Situational Method, and The Audio-Lingual Method, The Bilingual Method, The Communicative Language Teaching (CLT), The Total Physical Response, The Silent Way, The Eclectic Approach are most common methods of teaching and learning.

For these reasons stated above, teaching English using an appropriate method in tertiary level cannot be ignored and avoided. To desire and make a successful educational goal both for individual institution and students, teaching English in own dynamic context is a challenge for university teachers. But one method is not adequate enough to solve all the problems in language

K C AL-KINDI CENTER $R$ D FOR RESEARCH AND $R$ D DEVELOPMENT Your gateway to world-class research

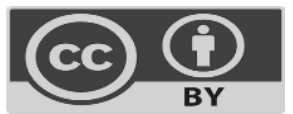

Published by Al-Kindi Center for Research and Development. Copyright (c) the author(s). This open access article is distributed under a Creative Commons Attribution (CC-BY) 4.0 license 
pedagogy. So, it is wise decision to use principle, techniques, and ideas from several methods in one lesson which can be called eclecticism.

My focus, according to the demand of the title will be basically on eclecticism in teaching English, tertiary level (the university level after intermediate in Bangladeshi context) and private and public universities, introducing new technique for better learning, changes in teaching practices-their beliefs, principles, and implication of future trends and constraints. The discussion will be on eclectic method already exercised in those above-mentioned universities. Another focus will be on alternative techniques and strategies followed in tertiary level of teaching English as a second language. As one method has its strengths and weaknesses, the paper's main target is to discuss an innovative learning style. Some practices will be suggested based on music videos and other lyrical songs (a very unique text type) to involve the students directly and create their interests through some interesting activities. This, I found very fruitful and flexible and it always fulfils the demand and interest of students. At the end, I will share some results what I found after discussing issues related to my study.

\section{Literature Review}

\subsection{What is Eclectic Approach and What does eclecticism mean?}

Eclectic approach means a combination of many methods deriving from many other principles, techniques and processes. By definition, Kumar (2013) noted that "the eclectic method is a combination of different methods of teaching and learning approaches". This method initiated in 1990s and became popular this decade. The term "Principle Eclecticism" was advocated and used by Larsen-Freeman (2000) and Mellow (2000) who describes 'a coherent, flexible, and pluralistic approach to language learning and teaching'. As individual method has its own constraint, Brown (2002) argued that eclecticism provides the solution because the approach allows the teachers to select and decide what is beneficial and helpful in their own particular dynamic context. Since it is context sensitive, learning is relaxed and fun for learners. A teacher has freedom to choose what works better in which situation as Mwanza (2019) describes.

Furthermore, Gao (2011, p.1) describes eclectic approach as not a "concrete, single method, but a method which combines listening, speaking reading and writing and include some practices in the classroom." By adding, he proposes that a teacher should integrate many methods to take advantages and avoid single ones' disadvantages.

Like other language education approaches, the Eclectic Approach has some inherent principles. Perhaps, the main principle of this approach is that the language teacher can choose any suitable methods or techniques befitting the needs of the learners and learning situation. The following principles as presented by Al-Khuli M. Ali (1981:7) may be considered: $\neg$ Giving teachers a chance to choose different kinds of teaching techniques in each class period to reach the aims of the lesson; $\neg$ Flexibility in choosing any aspect or method that teachers think suitable for teaching inside the classroom; $\neg$ Giving a chance to pupils to see different kinds of teaching techniques that break monotony and dullness on one hand and ensure better understanding of the material on the other hand.

\section{2. 'Need Analysis' and Eclecticism:}

According to Pratt, (1980) need analysis is defined as "an array of procedures for identifying and validating needs, and establishing priorities among them" (P.79). According to Coffing, (1974) need assessment answers the question "Who needs What, as defined by Whom" (p. 17). Most authors divide the needs into two broad categories: objective needs and subjective need. Objective needs rest on the collection of various types of biographical information. These may include general information like current proficiency, level, age, education background, previous experience, nationality etc. Subjective needs of learners relate to learners' perceptions of what they want to learn and how they want to learn it. Some private university students are very fluent in speaking without the grammar knowledge as we see from their presentation skill. On the contrary, public university students are not that much outward and smart in speaking. So, their learning styles, strategies, needs are different. Witkin (1984) talked about need assessment and Nunan (1988), commenting on objective needs analysis, says that objective needs help in content specifications derived from an analysis of the target communicative situations in which learners are likely to find out themselves.

After analysing the needs of learners, a method should respond to learners' needs, not learners and teachers respond to the method. According to Wali, (2009) as he summarized a proposition and stated, one of the premises of eclecticism is that teaching should serve learners, not methods. In American International University-Bangladesh (AIUB) where I taught for three years, I found that the foundation courses were designed for them to be competent in business communication, in some cases, for building up their writing skills as well. But here in Bangabandhu Sheikh Mujibur Rahman Science and Technology University (BSMRSTU), I found that the foundation course syllabus is designed for learning grammar items mostly. Most of the students are lacked behind because of less fluency and not proficient in their communicative skill. The focus of my learning objectives and teaching goals are different in two settings. 


\subsection{Application of Eclectic method for Bangladeshi English language learners:}

Some of the befitting good ideas, principles, and techniques are synthesized and blended harmoniously in eclectic method. Here a teacher should consider the abilities, background and problems of leaning. One particular method is not good enough to make students communicatively competent. But eclectic method is a possible solution as the focus is on speaking, listening and two other skills. We know that the real life practice in classroom context is different from our own perceptions. The Direct Method was introduced in 1900 as an alternative for teaching a foreign language or a second language from other previous methods. It aims at establishing the direct bond between thought and expression, experience and language. The main objective was to develop communicative competence among the students. Later, Communicative Language Teaching (CLT) or communicative approach was introduced in 1970s and 1980s and became very popular in English Language Teaching. The concept mainly emphasizes on active learning, not passive leaning. According to Michael Canale \& Swain (1980), Communicative Competence is defined in terms of three components, grammatical competence, socio-linguistic competence, strategic competence. Here a teacher does not use prescribed textbook always. A teacher focuses on needs of learners. Nunan (1988) and Tarone \& Yule (1989) focus on language learners in their learner centered curriculum design. Eclectic method is more preferable than any other methods in designing course curriculum as it is the juxtaposition of all principles.

In Bangladesh, there are many public and private universities. In both universities, teachers are trying hard to find exact and flexible teaching methods. As a language practitioner, it is high time not to depend on only one single method, especially in tertiary level. In the language classroom, a teacher has to provide multiple opportunities for students so that they can learn very effectively. In such a situation, eclecticism encourages the use of a variety of language learning activities, each of which may have very different characteristics and objectives and underlying assumptions. The teacher can use a variety of strategies to make language comprehensible, monitor student comprehension, and make adjustments as necessary.

In private institutions, the number of students is less than the number of students in public universities. There are many other differences in background, setting, facilities, infrastructure, classroom facilities etc. According to the differences, students should be treated and dealt with differently. In many researches, we found that students are not well equipped with instruments and other advantages of learning. In public universities, they take English as non-major or foundation course. In private universities, the situation is the same.

The primary focus of English language learning is to learn all four skills and be competent enough to listen, learn and write in different situations. Many students tend to imitate accent without knowing the forms and structures. In that case, vocabularies, pronunciation, forms are not separate entities. Students must acquire and learn, they should be aware of contextual and cultural varieties so not a single skill should be left behind. Kumar (2013) supports the Eclectic Approach and declares, "The purpose of advocating eclectic method is to connect life experiences to the ideas presented in learning of the language. The types of learning activities teachers select are often directly related to their experiences in the real world." Brumfit (1984) emphasized that eclecticism was a right approach for language teaching and he further commented on language learning, "Language learning program should provide a balance of activities such as accuracy and fluency. Accuracy focuses on form and fluency on exchanging meaning, accomplishing tasks and reaching outcomes." Thus, many teaching experts have supported the Eclectic Approach for teaching languages, particularly ELT. According to Rao's (2018) speech, "the multiple line of Eclectic Approach embodies the principle that gives the opportunity to choose judiciously and helps the teachers in their work. 'Eclecticists 'seek the balanced development of all four skills at all stages while emphasizing the early development of aural-oral skills. An eclectic teacher has to be imaginative, energetic and willing to experiment for the purpose of keeping lessons varied and interesting". To agree with them, my proposal is to follow eclecticism and create new innovative ideas and techniques to learn and teach language as a whole.

\section{Methodology}

In this paper, I included my own literature reviews; I followed qualitative research and observation; my focus group was tertiary level second language learners; examine and analyze the task and assignment papers. Some innovative, authentic and exclusive techniques which have been used in my classrooms in private and public universities, I have documented their assignments and collect data through email submission of assignment. I will show and discuss problematic issues by critically evaluating some experiences I gathered from classroom practices. An Eclectic approach is followed in classrooms and the result is found by observing and analyzing home tasks and answer sheets from their classroom performances. So, it is more or less experimental.

\subsection{Proposal of an innovative activity for Bangladeshi tertiary level students}

Instead of using written texts of target language, we can use different contextual and cultural varieties. Here, I propose a very unique example of activity to ensure better learning. As texts can be of different kinds, a music video, a song, a lecture, a dialogue, and a written document are all different types of texts. 
As a teacher, in my classroom, I make my students listen, watch, read, understand, speak, and write all together in one session. Learning English as a whole requires these activities. How this is possible is the principle overview of my article. Here I would like to share an objective of acquisition and learning English below:

\section{Lesson Plan for a single class}

\section{For an English Language Class of Tertiary Learners}

3.1.1. Objective: To develop learners' critical thinking ability through listening and speaking mostly and to practice reading and forms of writing.

\section{Learners' Profile:}

\begin{tabular}{|l|l|}
\hline Number of students: & $40-60$ \\
\hline Age: & $21-23$ \\
\hline Proficiency level: & Tertiary \\
\hline Learners Backgrounds: & Bangla \& English medium schools and colleges \\
\hline Sex: & Mixed \\
\hline
\end{tabular}

Text Type:

Logistic Support:

Class Duration:
Songs

White board, Marker, Duster,

Projector, Sound box, Computer

75 minutes

Warm- up Session: Students are asked some questions like-

1. What type of music do you listen more often and like most?

2. What are the common themes of a song?-Love, Friendship, Relationship, Separation, etc.

3. Do these types of love songs reflect reality or do you think they are too much unrealistic?

4. What are the qualities that make a love song more appealing and life-like?---- the life-like story, characterization

5. What kind of character-traits makes a character more interesting and memorable?

Listening Session: Students are divided into 8 groups and asked to listen and take notes to get the main ideas of the three songs. First song- "Don't Cry Joni", Second song-"Secret Love Song", Third Song-"Broken Angel"

(9 minutes)

For example-you will have to think about what's happening, for example you need to find out the story, characterization, ending of the songs. After that you will have to do some activities. 


\subsubsection{Group Work:}

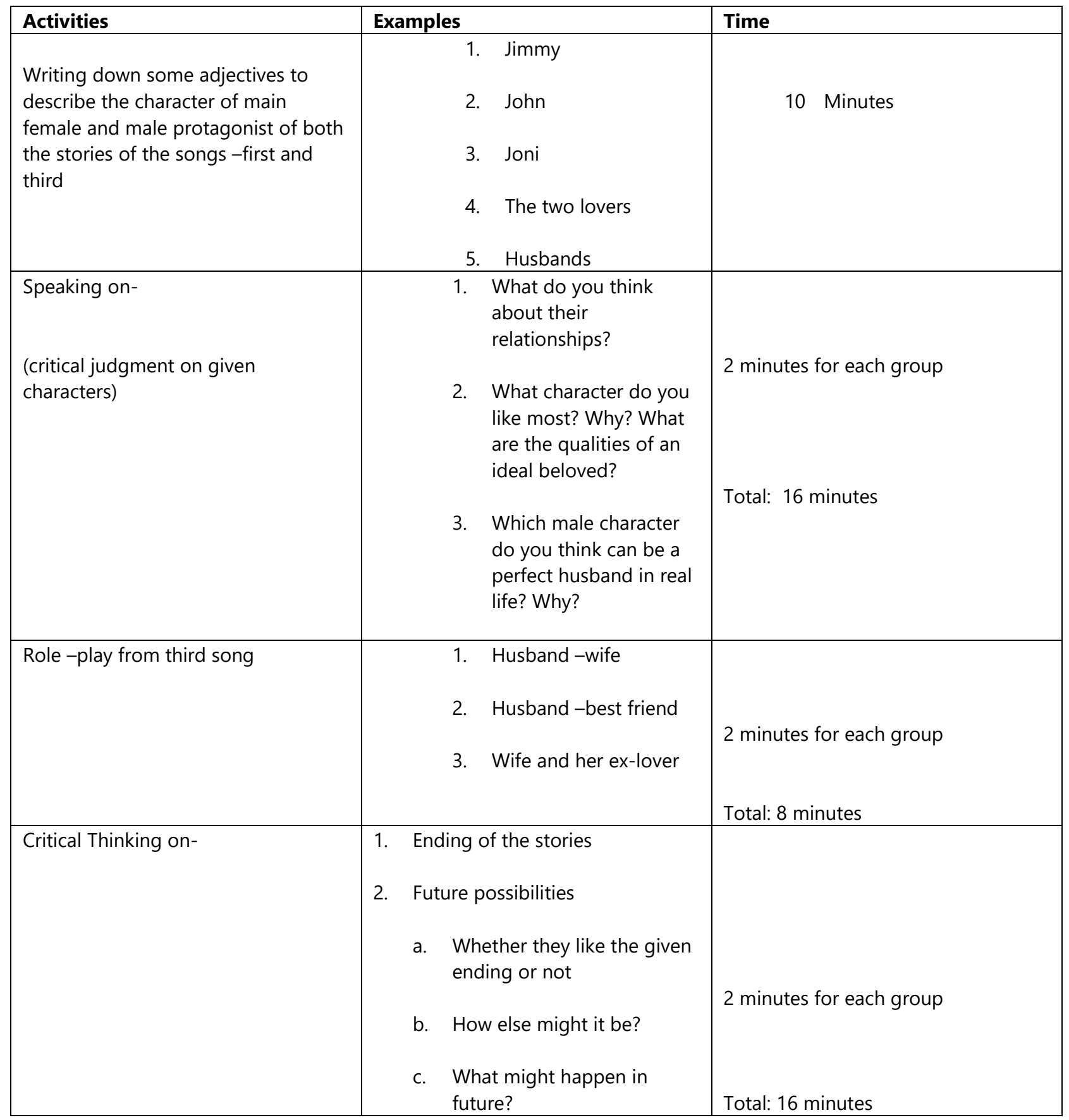

Assignment: Students are asked to form groups and find out a Bangla song to compare and contrast the stories, characters, their relationships with those of English songs for the next class. From the second song, they are asked to do some tasks complete the exercise given at the end of lyrics. The song is given below: 
Song-2

Little Mix-Secret Love

Why can't it be like that? Cause I'm yours

[Verse 1: Jade \& Jesy]

We keep behind closed doors

Every time I see you, I die a little more

Stolen moments that we steal as the curtain falls

It'll never be enough

It's obvious you're meant for me

Every piece of you, it just fits perfectly

Every second, every thought, I'm in so deep

But I'll never show it on my face

[Pre-Chorus: Jesy]

But we know this, we got a love that is hopeless

[Chorus: Perrie]

Why can't you hold me in the street?

Why can't I kiss you on the dance floor?

I wish that it could be like that

Why can't we be like that? Cause I'm yours

[Verse 2: Jason Derulo]

When you're with him, do you call his name

Like you do when you're with me? Does it feel the same?

Would you leave if I was ready to settle down?

Or would you play it safe and stay?

[Pre-Chorus: Jason Derulo]

Girl you know this, we got a love that is hopeless

[Chorus: Perrie \& Jason Derulo]

Why can't you hold me in the street?

Why can't I kiss you on the dance floor?

I wish that it could be like that

Why can't we be like that? Cause I'm yours

[Bridge: Jason Derulo \& Leigh-Anne \& Jesy]

And nobody knows I'm in love with someone's baby

I don't wanna hide us away

Tell the world about the love we making

I'm living for that day

Both - Someday

Why can't I hold you in the street?

Why can't I kiss you on the dance floor?

I wish that we could be like that

Why can't we be like that? Cause I'm yours, I'm yours 


\subsubsection{Some questions to exercise in the class or may be given as assignment}

Question-1: What is the basic grammar difference between "it's" and "its". Explain your answer with example.

Question-2: What are some examples of short forms (like it's, can't) used in this song as lyrics? Write at least 5 meaningful sentences on your own using 5 examples.

Question-3: Write some informal words used in all the songs. Make them formal.

$\underline{\text { Informal words/phrases }}$

Formal Words/Phrases

Question-4: Write three Open questions and three Closed questions on the basis of the lyrics.

Some pronunciation practice: dance /da:ns/, meant/ment/, can't /kant/, that /ðat/,

For learners, the above exercises are quite simple and suitable to understand underlying grammar rules and practice them smoothly. They are assigned to do it in groups which may help them promote adult learning, encourages learners to solve problems, connect, prioritize, and incorporate conceptual knowledge. It affects the development of attitudes and values of social and intellectual experience. At last, it develops oral presentation skills while they will be asked to talk about story ending, characters, plot etc. along with pronunciation. An exercise sheet is shared here to show how an individual student finds out examples of same question structure and can write down properly.

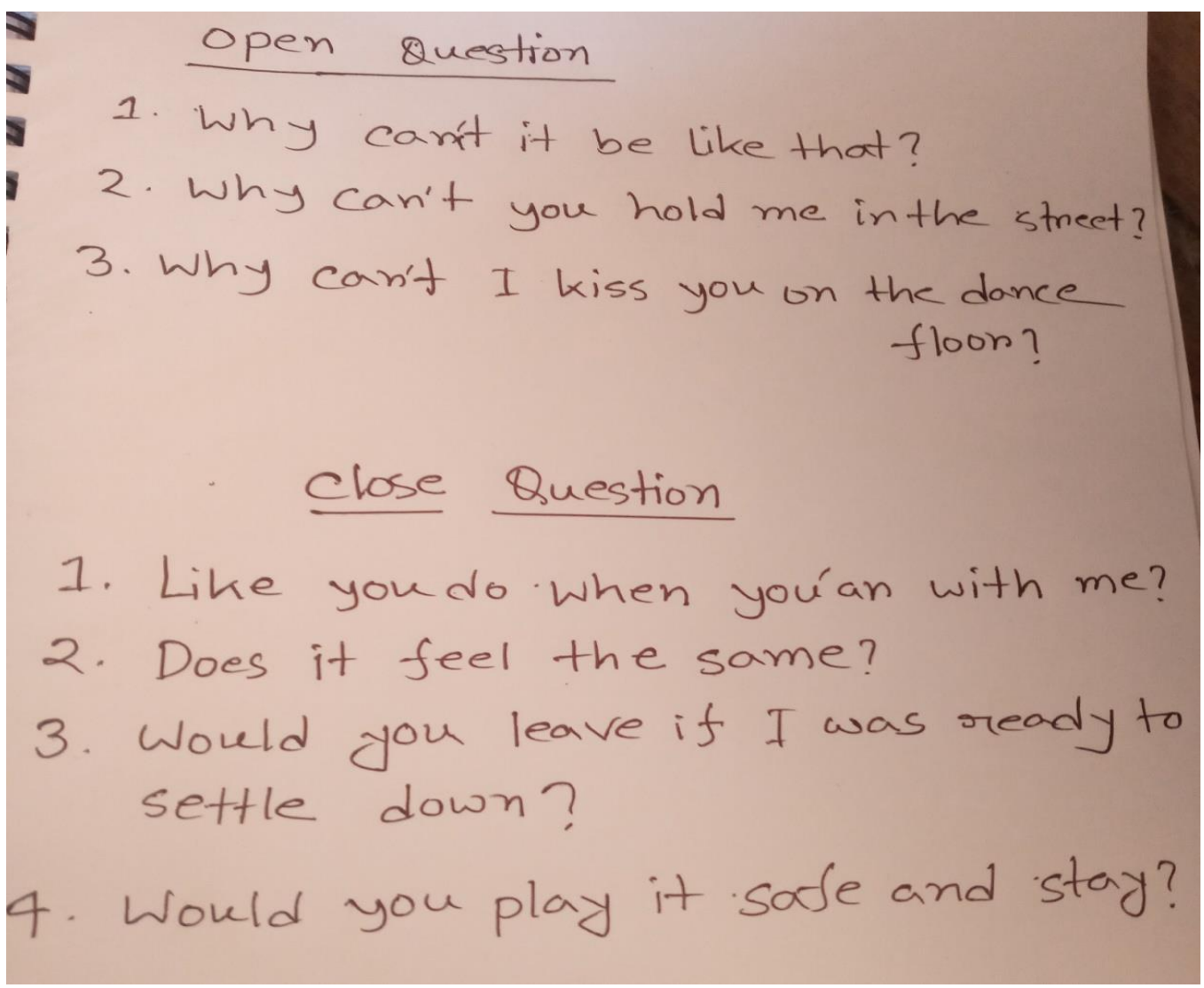

From the above exercise of a student, it is clear that he can identify other similar structure of open and closed questions from the given lyrics. Although some answers are wrong, they do not feel any burden or pressure to learn after the end of the class. The exercises are very interesting, not at all boring and dull.

\section{Discussion and results}

In the objective stated above, all skills are practiced. After they listen songs, some of the lyrics can be practiced further. For example, from the second song, "why can't we be like that?"; "Does it feel the same?" ; "I wish we could be like that"- these three lyrics give us three forms, WH question format or open question format, closed question format and an optative sentence structure. We can practice and ask students to write format like- in open question, the format is -'Wh question mark+ auxiliary verb + subject+ main verb+ object/adverb' and in optative complex sentence, the structure is- 'Subject+ Wish+ Subject+ Verb(past form)' . These are found from the lyrics of the played song so that students can get them connected and make them 
interested. Students can find out several other short forms or verb contractions, formal-informal words, vocabularies, pronunciation, on the basis of comparison between two cultural contexts.

Here in this discussion, sharing the real life exercise sheet and task of a student helps my analysis and makes it clear to readers. From the objectives shared above, the students listen to song, read lyrics to understand and follow pronunciations, speak/discuss on it, write about forms, characters, plot, ending, and give more examples.

From the real-life example, it is very clear that language teachers can apply and create different unique models of activities to ensure an approach to learning vocabularies, grammar, pronunciation, and spoken English. Students can get chance of doing peer work/group work, learn language as a whole, learn in a very different unique way maintaining a procedure that may seem a combination of many techniques. As music is a part of culture and context, more or less everybody loves to listen to music. If students are involved in group activities, they can communicate and do tasks effortlessly. Once they understand the underlying Grammar forms, they will never feel pressurized by drills, translation rather by audio-visual effect, they can be benefitted and relaxed. In both universities, I get positive responses and work best for all students.

\section{Probable Problems and Solution}

In both settings, teachers may face difficulties accomplishing activities. I have applied the same method eclectic method in both cases. Students in private universities do not ask for interpretation in Bangla (first language), but most students (almost 60\%) of public universities ask for clarification in their first language or Bangla. They have poor listening skill. I am astonished to find that students even don't know the meaning of easy vocabularies. They cannot find out difference between "its" and "it's"; they do not know question format; many of them start writing using small letters; they do not have knowledge about formal academic writings; their reading skill is not satisfactory; they do not understand enriched or technical words. Public university students' problems are: they are fluent without enough grammatical knowledge; they use lots of fragments subconsciously both in writing and speaking. These are the problems related to students' proficiency. A teacher may face many more problems: a teacher needs to deal with huge number of students in one classroom, so feedback of their tasks and assignments cannot be given within given time. Most of the rooms do not have projector and sound system; most of them are not well-equipped. Language labs are not furnished well to conduct a music class because of the shortage of instrument. As their listening skill is poor, a teacher may get into trouble to understand the lecture and fail to discover the objective of their learning. While managing everything, a private university teacher does not have to worry because the students are very less in number compared to public university classroom. So, ultimately the needs assessment of each perspective is different. A teacher needs to conduct a class in such a way that all of them get support and care which becomes very tiresome for teacher. The same class objective, teaching style, technique may not work for these two institutions although they are all tertiary level learners. Students may get exposed to several other problems.

The only solution of this problem is to initiate a new innovative idea to explore. In this respect, a single method cannot give you a reliable solution. For example, GTM does not focus on speaking; there is always absence of modern communicative English that is needed for various situations. In eclecticism, the teaching of English involves students in many situations. By creating situations, the target language can be made more understandable. This method provides an opportunity for role-playing and real world game activities. It facilitates the achievement of objectives. It ensures constant reflection, feedback and judgment of teacher. Eclectic approach can be regarded as a combination of Direct, Situational and Communicative Approach. According to Weidman (2001:2), "The Eclectic Approach has been widely accepted in English classrooms that many good teachers today use it proudly as a tag to describe to their teaching, wearing it almost like a badge of honour". Overall, eclecticism is one of the best successful approaches.

\section{Conclusion}

From the core analysis of disadvantages and shortcomings of a particular method, it is evident that the eclectic approach is mostly favored and appreciated. It serves the purpose of learning and enables them to learn spontaneously. Teachers need to keep in mind that one single method is rigid and monotonous. The above suggested practical objective gives us a clear instruction of how a teacher integrates all resources and activities. The variety of oral and written exercises helps students improve the communicative abilities with fluency and accuracy. In spite of having problems, every learner finds it easy to learn in a novel innovative interesting environment created by a teacher. It can be a potential topic for future M. Phil or PhD research. More observation and both qualitative and quantitative method should be followed to have a clear concept about the result of justified application of eclecticism in Bangladeshi higher level teaching context. The research will obviously help improve quality language teaching. After finding out results, foreign institutions around the world can apply the similar techniques with a positive attitude to it. 


\section{References}

[1] Ali, A.M. (1981). Teaching English to Arab Students. Jordan: Al Falah House.

[2] Brown, H.D. (2002). Methodology in Language Teaching: An Analogy of Current Practice. Cambridge University Press, 9-18

[3] Brumfit, C (1984). Communicative Methodology in Language Teaching. Cambridge University Press.

[4] Canale \& Swain (1980) Theoretical bases of communicative approaches to Second language teaching and testing. Applied Linguistics. 1(1), pp. $1-48$

[5] Coffing, R. T, \& Hutchinson, T.E. (1974). Need Analysis Methodology: A Prescriptive Set of Rules and Procedures for Identifying, Defining and Measuring Needs. Chicago, IL: paper Presented at American Educational Research Association Annual meeting (ERIC Document Reproduction Service No. ED 09654).

[6] GAO, L. (2011). Eclecticism or Principle Eclecticism. Creative Education. 2(4), 63-369

[7] Kumar, C. P. (2013). The Eclectic Method: Theory and Its Application to the Learning of English. International Journal of Scientific and Research Publication, 3(6).

[8] Larsen \& Freeman. (2011). Techniques and Principles in Language Teaching (With M. Anderson). Third Edition. Oxford. Oxford University Press.

[9] Mellow, J.D. (2002). Towards Principle Eclecticism in Language Teaching: The two Dimensional Model and Centering Principle. Teaching English as a Second Language Journal, 5(4): A-1

[10] Mwanza, D. S. (2016). A Critical Reflection on Eclecticism in the Teaching of English Grammar in Selected Secondary Schools in Zambia. PhD Thesis, University of Western Cape.

[11] Mwanza, D. S. (2019). The Eclectic Method to Language Teaching: Clarifications and Conceptual Extensions. Journal of Lexicography and Terminology, 1(2).

[12] Neuber, K.A. (1980). Communicative Syllabus Design. Cambridge University Press.

[13] Nunan, D. (1988). The Learner Centered Curriculum. New York: Cambridge University Press.

[14] Pratt, D. (1980). Curriculum Design and Development. New York: Harcourt Brace Jovanovich.

[15] Rao, P. S (2018). Eclectic Approach in English Language Teaching: A Comprehensive Study. An International Multidisciplinary Journal. 8(10). ISSN 2249-7137

[16] Tarone, E. \& Yule, G. (1989). Focus on the Language Learner. Oxford: Oxford University Press.

[17] Wali, N. H. (2009). Eclecticism and Language Learning. Al- Fatih Journal. No.39. Diyala University-College of Basic Education.

[18] Weidman, A. (2001). The Old and the New: Reconsidering Eclecticism in Language Teaching. Linguam, 17(1), pp.1-13. Doi.org/10.5785/171-131.

[19] Witkin, B.R. (1984). Assessing Needs in Educational and Social Programs. Jossey-Bass Inc, Publishers. 